Social Media and Technology, 1:1 (2016), 40

ISSN: 2468-2128

Competence in Information Technology of the Faculty of the College of Technical Education

Aloysius J. Aurelio ,*, Noemi M. Boado, Remalyn Q. Casem, Myal A. Guba ,

Don Mariano Marcos Memorial State University, PHILIPPINES

*Correspondence to: aloy_aurelio@yahoo.com

\title{
ABSTRACT
}

This study assessed the competence in Information Technology of the members of the faculty of the College of Technical Education. Employing the descriptivecorrelational research design, 45 of the 60 faculty were studied through a validated selfmade research instrument. All of the respondents showed some familiarity with information technology particularly computers and peripherals. They had good exposure to computer use and rated very competent in information technology. The study showed that there is a decline in the degree of competence of the respondents with academic rank. But with periodic use of computers, the respondents manifested improved competence. Other factors like gender, degree earned, designation, specialization, subjects taught, highest educational attainment, years in service, and ITrelated trainings attended did not show significant relationship with the degree of competence.

Keywords

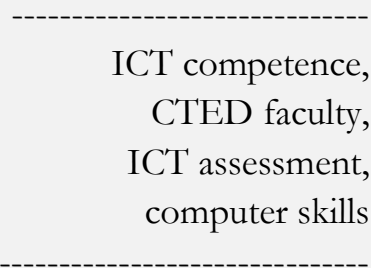

Received: 13 January 2016

Accepted: 1 March 2016

Published Online:8 August 16

DOI: $10.20897 /$ lectito.201640

\section{Background/Objectives and Goals}

Information and Communications Technology (ICT) is defined as the totality of electronic means to collect, store, process and present information to end-users in support of their activities. It consists, among others, of computer systems, office systems and consumer electronics, as well as networked information infrastructure, the components of which include the telephone system, the Internet, fax machines and computers (NICS Handbook). ICTs at present are influencing every aspect of human life. They are playing salient roles in work places, business, education, and entertainment. Moreover, many people recognize ICTs as catalysts for change; change in working conditions, handling and exchanging information, teaching methods, learning approaches, scientific research, and in accessing information (Mikre, 2011). In addition, according to Ogbomo and Ogbomo (2008), in their study on the importance of ICT, respondents use ICTs for capacity building, improvement of teaching conditions, job creation, increased in income, improvement of agricultural production, greater involvement in community matters, better use of information, improvements in contact with relatives and friends, and time saving. Also, Arroyo (2005) on her presidential speech about ICT and the Strong Republic School, she emphasized that ICT is one of the galvanizers of economy, highlighting that the dream of attaining a strong and vibrant nation is empowered by education and ICT.

Competence in ICT is no doubt an advantage in the workplace. Perkins (n.d) emphasized that teaching people how to be competent basic users of ICTs is important so they will be successful in their academic and work careers, and so they can efficiently participate in modern technical society.

In educational institutions, the indispensable use of ICTs specifically computer and its peripherals cannot be underestimated. In the school, where there is plenty of paper works, records keeping, database management and processing, desktop publications, presentations and the like to be done, sets of computers have become a fixture in almost every learning corner. In addition, according to Charlie (2012) computers are also used in e-learning, social networking, teaching aid, learning aid through internet and teaching assessment aid.

Faculty members being the number one agents in education play a significant role in computer utilization. Hence, their knowledge on the proper usage and handling of computer, both hardware and software, should be paid with much attention. Assessment of how competent they are to handle computers is needed to be able to determine what level are they in as to computer use. This determines how well they can do their jobs with the use of computer. This study generally aims to determine how capable the members of the faculty of CTED can manage to utilize computer hardware and software, as well as peripherals in discharging their work in and out of the classroom. Specifically, it sought answers to the following: (1) What is the profile of the respondents in terms of 
gender, age, academic rank, highest educational attainment, number of years in the service, area of specialization, designation, subjects taught, number of seminars/trainings in IT attended, and average number of hours spent in using computers and peripherals per week?; (2) What is the extent of exposure of the respondents to the use of computer hardware and peripherals and common computer application software particularly MS Word, MS Excel, and MS PowerPoint?; (3) What is the degree of competence of the respondents in Information Technology?; (4) Is there a significant relationship between the competence of the respondents in information technology and their profile?

\section{Methods}

This study employed the descriptive-correlational research design. First, it investigated the profile of the respondents and their prevailing competence in the use of information technology. Then these were correlated to establish possible connections. According to Best and Kahn (2006), descriptive research deals with the relationships between variables, the testing of hypotheses, and the development of generalizations, principles, or theories that have universal validity. Zechmeister(2000) described correlational research to represent a general approach that focuses on assessing the covariation among naturally occurring variables. The goal of correlational research is to identify predictive relationships by using correlations or more sophisticated statistical techniques.

After having identified the specific problems, a research instrument was formulated and subjected to face and content validation by five faculty members who are experts in the field of information technology. The instrument was determined to be Highly Valid in both face and content. It was then pilot tested to ten faculty members from other colleges. It has a KR-20 reliability value of 0.89 (Very High). Final revisions were incorporated based on the comments and suggestions of the validators. The instrument consisted of a part for the profile of the respondents and a part to determine the competence of the respondents in using information technology. The second part is a four-option multiple item test of 50 items.

Of the 60 faculty members of the College of Technical Education, 45 became actual respondents using the Lynch Formula. The data were then classified and summarized using Excel. For correlation analysis, SPSS Software was used.

To establish the profile of the respondents from the data, percentages based from frequency counts were used. To determine the extent of exposure of the respondents to the use of computer hardware and peripherals and the corresponding data were analyzed using the following scale:

Table 1. Scale for the Extent of Exposure on the Use of Computer Hardware and Peripherals

\begin{tabular}{|c|l|}
\hline Range & Interpretation \\
\hline $17-20$ & Highly Exposed (The faculty knows almost all the different computer hardware and peripherals) \\
\hline $13-16$ & Very Exposed (The faculty knows much about the different computer hardware and peripherals) \\
\hline $9-12$ & Exposed (The faculty knows moderately about the different computer hardware and peripherals) \\
\hline $5-8$ & Slightly Exposed (The faculty knows some computer hardware and peripherals) \\
\hline $0-4$ & Poorly Exposed (The faculty knows little about the computer hardware and peripherals) \\
\hline
\end{tabular}

To determine the extent of exposure of the respondents as to the use of common computer application software particularly MS Word, MS Excel, and MS Powerpoint, the following scale was used:

Table 2. Scale for the Extent of Exposure on the Use of Common Computer Application Software Particularly MS Word, MS Excel, and MS PowerPoint

\begin{tabular}{|c|l|}
\hline Range & Interpretation \\
\hline $25-30$ & $\begin{array}{l}\text { Highly Exposed (The faculty knows almost all the computer application software particularly MS } \\
\text { Word, MS Excel, and MS PowerPoint) }\end{array}$ \\
\hline $19-24$ & $\begin{array}{l}\text { Very Exposed (The faculty knows much about the computer application software particularly MS } \\
\text { Word, MS Excel, and MS PowerPoint) }\end{array}$ \\
\hline $7-18$ & $\begin{array}{l}\text { Exposed (The faculty knows moderately about the computer application software particularly } \\
\text { MS Word, MS Excel, and MS PowerPoint) }\end{array}$ \\
\hline $0-6$ & $\begin{array}{l}\text { Slightly Exposed (The faculty knows some use of common computer application software } \\
\text { particularly MS Word, MS Excel, and MS PowerPoint) }\end{array}$ \\
$\begin{array}{l}\text { Poorly Exposed (The faculty knows little about the use of common computer application } \\
\text { software particularly MS Word, MS Excel, and MS PowerPoint) }\end{array}$ \\
\hline
\end{tabular}

For the degree of competence, the following scale was used: 
Table 3. Scale for the Degree of Competence in Information Technology

\begin{tabular}{|c|l|}
\hline Range & Interpretation \\
\hline $41-50$ & $\begin{array}{l}\text { Highly Competent (The faculty knows almost all about the different computer hardware and } \\
\text { peripherals; and the use of common computer application software particularly MS Word, MS } \\
\text { Excel, and MS PowerPoint) }\end{array}$ \\
\hline $31-40$ & $\begin{array}{l}\text { Very Competent (The faculty knows much about the different computer hardware and } \\
\text { peripherals; and the use of common computer application software particularly MS Word, MS } \\
\text { Excel, and MS PowerPoint) }\end{array}$ \\
\hline $21-30$ & $\begin{array}{l}\text { Competent (The faculty knows moderately about the different computer hardware and } \\
\text { peripherals; and the use of common computer application software particularly MS Word, MS } \\
\text { Excel, and MS PowerPoint) }\end{array}$ \\
\hline $11-20$ & $\begin{array}{l}\text { Slightly Competent (The faculty knows some about the different computer hardware and } \\
\text { peripherals; and the use of common computer application software particularly MS Word, MS } \\
\text { Excel, and MS PowerPoint) }\end{array}$ \\
\hline $0-10$ & $\begin{array}{l}\text { Not Competent (The faculty knows little about the different computer hardware and } \\
\text { peripherals; and the use of common computer application software particularly MS Word, MS } \\
\text { Excel, and MS PowerPoint) }\end{array}$ \\
\hline
\end{tabular}

Correlation tools were employed to tackle the problem on the relationship between the profile and the degree of competence of the respondents. Specifically, Kendall's tau, a non-parametric correlation tool, was used to establish the relationship between the degree of competence and academic rank and highest educational attainment of the respondents. Ordinal regression was used to establish the relationship for the degree of competence and the profile such as gender, age, baccalaureate degree earned, highest educational attainment, number of years in service, area of specialization, designation, subjects taught, number of IT-related training attended, and the number of hours per week spent using computers.

\section{Results}

\section{On Profile of Respondents}

Gender. Of the 45 respondents, 34 were females and 11 were males. This is a common trend among teacher education institutions where females outnumber males. In the study conducted by Luan et. al (2005) on Gender Differences in ICT Competencies among Academicians at Universiti Putra Malaysia, it can be noted that there were more male respondents compared to female respondents.

Age. Eight $(17.78 \%)$ belonged to the age bracket of $35-39$ years old while the groups of $25-29,30-34,50-$ 54 , and $55-59$ each had $13.33 \%$. Only $2(4.44 \%)$ were as young as $20-24$ years of age, while 5 belonged to the "retirable" group $(60-64)$. It can be observed that the biggest number of respondents clustered around the middle age years.

Academic Rank. There were 26 or 57.78\% instructors, 11 assistant professors, 7 associate professors, and 1 professor. Majority of the respondents were still starting out in going up the academic ladder.

Baccalaureate Degree Earned. More than half of the respondents $(75.56 \%)$ were holders of education baccalaureate degrees, while just a few graduated with other degrees like industrial technology, business-related, and arts and sciences. No one had a degree directly related to information technology or even engineering. Although a teachertraining college, CTED is also manned by some non-education instructors but no one among the faculty holds an IT-related degree.

Highest Educational Attainment. In terms of highest educational attainment, 48.89\% finished a master's degree, $31.11 \%$ for baccalaureate degrees, and $20 \%$ hold a doctoral degree. The prevalence of those holding a master's degree can be attributed to the fact that this is a requirement for hiring and subsequently being given a permanent position.

Number of Years in Service. Sixteen respondents (35.56\%) had $0-5$ years of teaching experience, followed by those in the 26 - 30 years bracket $(22.22 \%), 13.33 \%$ had $16-20$ years of experience, while the remaining respondents were almost equally distributed in the other brackets.

Area of Specialization. The distribution of the respondents according to area of specialization was almost similar to that of baccalaureate degree finished. It followed that majority of the respondents specialized in education.

Designation. Seven (15.56\%) of the respondents had administrative designations, 9 (20\%) were coordinators/facilitators, while the remaining $64.44 \%$ (29 respondents) were not given any designation.

Subjects Taught. 28 respondents or about $62.22 \%$ handle general education courses, $10(22.22 \%)$ teach specialization courses, and the remaining $15.56 \%$ ( 7 respondents) take charge of professional courses. 
Number of IT-related Trainings Attended. Almost half of the respondents (42.22\%) had not undergone any IT-related seminar or training.

Number of Hours per Week Spent Using Computers. Eighty percent (36 respondents) spend more than 40 hours each week using a computer.

On Extent of Exposure on the Use of Computer Hardware and Peripherals and in Common Computer Application Software

Table 4A summarizes the percent of correct responses to items pertaining to the use of computer hardware and peripherals and Table 4B deals on the percent of correct responses to items pertaining to the use of common computer application software particularly MS Word, MS Excel, and MS PowerPoint.

Table 4A - Mean of Correct Responses to Items on the General Use of Computers and Peripherals

\begin{tabular}{|l|c|c|c|}
\hline Categories & Number of Items & Mean of Correct Responses & Percent \\
\hline Hardware Identification & 5 & 4.09 & 81.78 \\
\hline General Computer Use & 10 & 6.66 & 65.56 \\
\hline Printing & 5 & 3.27 & 65.33 \\
\hline Total & $\mathbf{2 0}$ & $\mathbf{1 4 . 0 2}$ & $\mathbf{7 0 . 1 0}$ \\
\hline
\end{tabular}

The respondents had the highest aggregate score equivalent to $81.78 \%$ in Hardware Identification. This was followed by General Computer Use and Printing. Apparently, they had the facility to identify computer parts and peripherals but relatively low in computer use including printing of documents. With the total mean of 14.02, the respondents were determined to be very exposed or they knows much about the use of computer hardware and peripherals. Goktas et.al (2009) revealed in his study on "Teacher Educators' ICT Competencies, Usage, and Perceptions" that computer hardware was the most used ICT hardware

Table 4B - Mean of Correct Responses to Items on the Common Computer Application Software Particularly Microsoft Word, Microsost Excel, and Microsoft PowerPoint

\begin{tabular}{|c|c|c|c|}
\hline Application Software & Number of Items & Mean of Correct Responses & Percent \\
\hline MS Word Processing & 10 & 6.42 & 64.20 \\
\hline MS Excel Spreadsheet & 10 & 5.91 & 59.10 \\
\hline MS Powerpoint Presentation & 10 & 6.49 & 64.90 \\
\hline Total & $\mathbf{3 0}$ & $\mathbf{1 8 . 8 2}$ & $\mathbf{6 2 . 7}$ \\
\hline
\end{tabular}

On the use of common computer application software particularly MS Word, MS Excel, and MS PowerPoint, the respondents scored almost equally for word processing and presentation at $64.20 \%$ and $64.90 \%$ respectively. They got about $59.10 \%$ corrct responses on the use of the spreadsheet MS Excel. In the study of Amuche and Iyekekpolor (2014), the main skill acquired by the teachers is in Word processing which can be attributed to typing of examination, test questions, student record and so on by the teachers.

\section{On Degree of Competence in Information Technology}

To determine the degree of competence of the respondents in Information Technology, the mean of their respective scores out of 50 items was computed. This came out to be 32.73 . Based on the scale, this is interpreted to be Very Competent. The faculty knows much about the use of common computer application software particularly MS Word, MS Excel, and MS PowerPoint. This result is opposite to the result of the study conducted by Archibong, et.al (2010) which revealed that competence in ICT of the academic staff is low which was attributed to no funding for ICT training, less ICT facilities and excess work load which does not give them time to train or even improve upon their ICT skills.

\section{On Relationship between the Degree of Competence and Respondents' Profile}

Table 5 reflects the relationship of degree of competence and academic rank and highest educational attainment using Kendall's tau as a correlation tool.

Table 5. Correlation for degree of competence and academic rank and highest educational attainment

\begin{tabular}{|c|c|c|}
\hline Profile of Respondents & Correlation Value (r) & P-value \\
\hline Academic Rank & $-0.329^{*}$ & 0.015 \\
\hline Highest Educational Attainment & -0.169 & 0.211 \\
\hline
\end{tabular}

* Significant at 0.05 level 
Academic rank showed a negative significant correlation with the degree of competence. This means that competence in computer seem to be lesser with higher faculty academic rank. It can be noted that most of the respondents occupying lower academic ranks are young and so they are more technology-adaptive.

Ordinal regression showed that number of hours spent was the only variable in the profile of the respondents which has a significant relationship with the degree of competence. The negative coefficient indicates that the more skilled a faculty in computer, lower contact hours is required. The result seems to be unusual since in practice, the longer hours spent in the computer, more skills are to be learned. This result has something to do also with the adaptivity of younger faculty as to computer usage.

Table 6 shows the result of the computation.

Table 6. Correlation for Degree of Competence and Other Profiles

\begin{tabular}{|c|c|c|}
\hline Indicators & Ordinal Regression Coefficient & P-value \\
\hline Gender & 0.616 & 0.361 \\
\hline Age & 20.653 & 0.997 \\
\hline Baccalaureate Degree Earned & $-2.05 \times 10^{-16}$ & 1.000 \\
\hline Number of Years In Service & 38.828 & 0.939 \\
\hline Area of Specialization & 1.293 & 0.586 \\
\hline Designation & 0.427 & 0.594 \\
\hline Subjects Taught & 0.754 & 0.285 \\
\hline Number of IT-related Training Attended & -1.017 & 0.612 \\
\hline Number of Hours per Week Spent Using \\
Computers
\end{tabular}

** Significant at 0.01 level

The other indicators did not show significant relationship with the competence of the respondents whether positively or negatively. It doesn't seem to matter much whether a faculty member is a male or a female, has finished just a bachelor's degree, has designation or a plain faculty, specializes in IT or any technology course, teaches a particular course or not, young or old, young or old in service has undergone IT-related training or not, and has gone to graduate school when it comes to showing competence in information technology.

The result of the study is in consonance with the study of Muflih and Jawarneh (2011) with regards to gender and years of teaching experience or years in service. According to their study, there was no difference between the female and male respondents in their level of possession of ICT and the degree of adoption of these technologies as a teaching tool. Regarding the years of teaching experience, faculty members possessed the same level of ICT skills and had the same level of adoption of ICT skills in instruction.

Also in the study of Tweed (2013), age, years of teaching experience, gender and hours spent in technology professional development (equivalent to number of it-related training attended in the study) had no relationship with technology use of teachers.

\section{Recommendations}

1. Faculty members of the College of Technical Education, especially those of younger age can be tapped to help other faculty members in doing tasks that require the use of information technology.

2. The College of Technical Education may consider providing greater access by the faculty members to the use of computers and peripherals to include internet for them to continuously improve their competence in utilizing information technology.

3. The College of Technical Education may implement a training on the use information technology for its faculty. 4. A follow up study may be conducted to assess the capability of the faculty members in more advance utilization of information technology resources.

\section{REFERENCES}

Amuche, Chris Igomu \& Solomon, A. Iyekekpolor. An Assessment of ICT Competence among Teachers of Federal Unity Colleges in North Central Geo-political of Nigeria. American International Journal of Research in Humanities, Arts and Social Sciences. ISSN (Print): 2328-3734, ISSN (Online): 2328-3696, ISSN (CD-ROM): 2328-3688. Retrieved from: http://iasir.net/AIJRHASSpapers/AIJRHASS14-158.pdf

Archibong, Ijeoma A., Joseph E. Ogbiji and Franca Anijaobi-Idem (2010). ICT Competence among Academic Staff in Universities in Cross Rivers State, Nigeria. Journal of Computer and Information Science. ISSN 1913- 


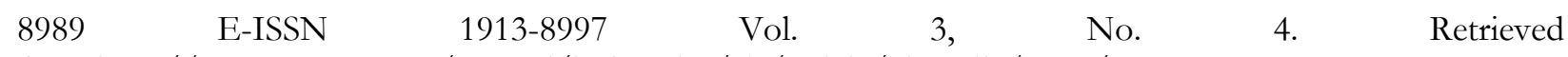
from:http://www.ccsenet.org/journal/index.php/cis/article/viewFile/7050/6119

Arroyo, Gloria M (2005). ICT and the Strong Republic School: In: Colinares, N, editor. Philippines Education in the Third Millennium: Trends, Issues and Challenges, Concerns. Philippines: 6Ns Enterprises; p. 1-4.

Best, John W. and James V. Kahn (2006). Research in Education, 10th Ed. USA: Pearson EducationInc.Retrieved from: http://www.academia.edu/5382594/Research in Education Tenth Edition

Charlie, S. (2012). Use of Computers in Education. Retrieved from:http://www.buzzle.com/articles/use-ofcomputers-in-education.html

Goktas, Yuksel; Soner Yildirim, and Zahide Yildirim (2009). Teacher Educators' ICT Competencies, Usage, and

Perceptions. Retrieved from: http://www.academia.edu/373362/Teacher_Educators_ICT_Competencies_Usage _and_Perceptions

Luan, Wong S., Sidek Abdul Aziz, Aida Suraya Mohd Yunus, Zakaria Sidek, Kamariah Abu Bakar, Hamidah Meseran and Hanafi Atan (2005). Gender Differences in ICT Competencies among Academicians at Universiti Putra Malaysia. Malaysian Online Journal of Instructional Technology (MOJIT), ISSN 1823-1144 Vol. 2, No.

3, pp 62-69. Retrieved from:http://unpan1.un.org/intradoc/groups/public/documents/apcity/unpan038246.pdf Mikre, Fisseha (2011). The Roles of Information Communication Technologies in Education Review Article with Emphasis to the Computer and Internet. Ethiopian Journal of Education and Sciences. ISSN: 1998-8907. Retrieved from: http://www.ajol.info/index.php/ejesc/article/view/73521/62437

Muflih, Mohammad Khaleefeh and Tariq Yousef Jawarneh (2011). An Examination of ICT Skills Possession and Adoption amongst Faculty Members at Jordan University of Science and Technology (JUST) in Relation to Rogers' Diffusion of Innovation Model. International Journal for Research in Education. Retrieved from: http://www.cedu.uaeu.ac.ae/journal/issue30/ch13_30en.pdf

National ICT Competency Standard (NICS) Basic Manual. Commission on Information And Communications Technology. Retrieved from: http://www.ncc.gov.ph/nics/files/NICS-Basic.pdf

Ogbomo, Monday Obaidievwe and Esoswo Francisca Ogbomo (2008). Importance of Information and Communication Technologies (ICTs) In Making A Heathy Information Society: A Case Study Of Ethiope East Local Government Area Of Delta State, Nigeria; Library of Philosophy and Practice.ISSN 1522-0222. Retrieved from: http://www.webpages.uidaho.edu/ mbolin/ogbomo2.htm

Perkins, Carl D (n.d). ICT Education. Mid-Pacific ICT Center. Retrieved from: http://www.mpict.org/ict_education_defined_importance.html

Tweed, Stephanie R. (2013). Technology Implementation: Teacher Age, Experience, Self-Efficacy, and Professional Development as Related to Classroom Technology Integration. School of Graduate Studies, East Tennessee State University. Electronic Theses and Dissertations. Retrieved from: http:/ /dc.etsu.edu/cgi/viewcontent.cgi?article $=2266 \&$ context $=$ etd

Zechmeister, Shaunessy (2000). Research Methods in Psychology, 5th Ed. Mc Graw Hill Companies. Retrieved from: http://www.mhhe.com/socscience/psychology/shaugh/ch04_summary.html 